\title{
Legitimacy of the G-20 as global financial regulator
}

Weber, Rolf $\mathrm{H}$

Posted at the Zurich Open Repository and Archive, University of Zurich ZORA URL: https://doi.org/10.5167/uzh-66773

Conference or Workshop Item

Published Version

Originally published at:

Weber, Rolf H (2012). Legitimacy of the G-20 as global financial regulator. In: Society of International Economic Law: The Third Biennial Global Conference, Singapore, 12 July 2012 - 14 July 2012. Society of International Economic Law (SIEL), 1-13. 


\section{THIRD BienNial GLOBAL CONFERENCE \\ JULY 12 - 14, 2012 \\ NATIONAL UNIVERSITY OF SINGAPORE \\ NUS FACULTY OF LAW \\ CENTRE FOR INTERNATIONAL LAW}

\section{LEGITIMACY OF THE G-20 AS GLOBAL FINANCIAL REGULATOR}

ROLF H. WEBER

ProfESSOR OF INTERNATIONAL BUSINESS LAW,

UNIVERSITY OF ZURICH, SWITZERLAND, AND

Visiting Professor, HONg Kong UNIVERSITY

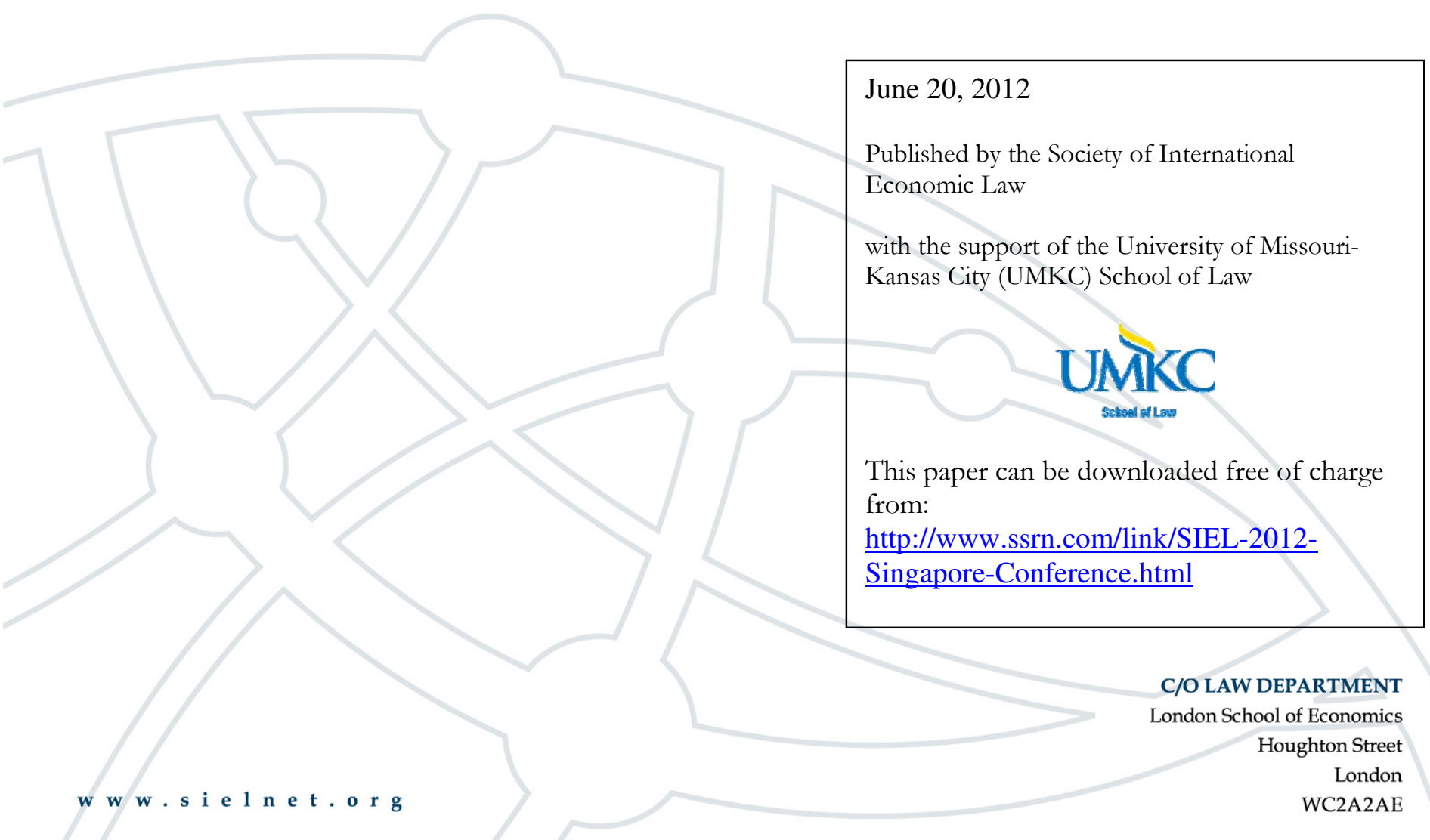


Prof. Rolf H. Weber*

\section{Legitimacy of the G-20 as Global Financial Regulator}

\section{Keywords:}

Concept of legitimacy, influence on financial regulation, informal law-making, processorientation of rule-making, regulatory topics

\section{Table of contents}

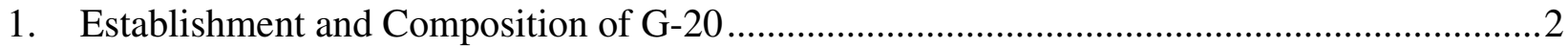

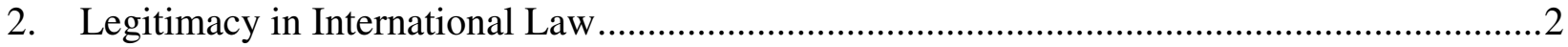

2.1. Notion of Legitimacy.......................................................................................

2.2. Concepts of Legitimacy ...................................................................................... 3

3. Involvement of the G-20 in Regulatory Topics ...............................................................

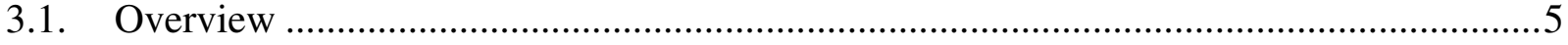

3.2. From Microeconomic to Macroeconomic Regulation............................................6

3.3. Reform of International Organizations .................................................................. 7

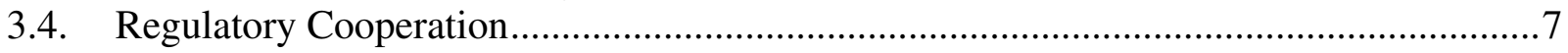

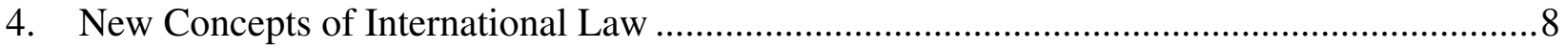

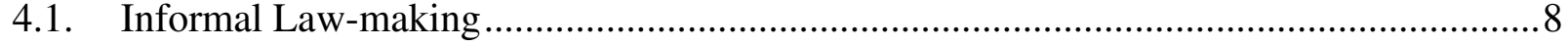

4.2. Incorporation of Norms through Informal Processes .......................................... 9

4.3. Elements of Legitimacy in Informal Situations................................................ 9

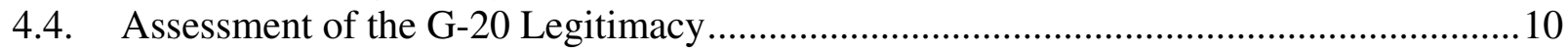

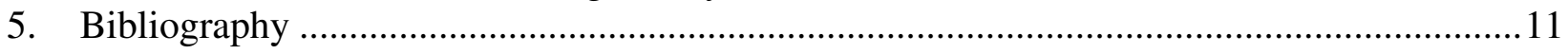

* Rolf H. Weber is professor of International Business Law at the University of Zurich, Switzerland, and Visiting Professor at Hong Kong University, Hong Kong. 


\section{Establishment and Composition of G-20}

The Group of Twenty (G-20) has been established as reaction to the Asian financial crisis of 1998/99; the new body was implemented as a forum for the Finance Ministers and Central Bank Governors at the Berlin meeting in 1999 with the objective of having the possibility to provide for an informal dialogue in the framework of the Bretton Woods institutional system. In the subsequent years, the activities of the G-20 have been relatively limited. As a reaction to the outbreak of the financial crisis in 2007/08 only, this forum has been "duplicated" by adding a (new) body of the "G-20 Leaders".

In fact, the G-20 was not designed to replace any existing institution, but rather as an organization enabling informal discussions and as a forum for debates which could facilitate the exchange of opinions between the formal international organizations. The key purpose can be seen in the attempt to offer opportunities for dialogues on international cooperation.

The G-20 is composed of 19 countries, namely: Argentina, Australia, Brazil, Canada, China, France, Germany, India, Indonesia, Italy, Japan, Mexico, Russia, Saudi Arabia, South Africa, Republic of Korea, Turkey, United Kingdom, and the United States of America. The $20^{\text {th }}$ member is the European Union, represented by the rotating Council Presidency and the European Central Bank (ECB). Representatives of IMF and World Bank participate in the G-20 meetings on an exofficio basis, but without voting rights.

The first meeting where the leaders of the G-20 countries gathered was the Summit on Financial Markets and the World Economy, held in Washington in November 2008. The subsequent London Summit of April 2009 intensively discussed the "Global Action for Recovery and Reform" and the strengthening of the Financial Stability Board (FSB). Thereafter, further summits were convened, respectively, on a half-yearly or yearly basis.

The Leaders of the G-20 Group do not pass legislation release laws, but declarations, communiqués, and other documents, expressing objectives in view of a political perception, not of a legal framework. Nevertheless, with the change of the level from finance ministers to leaders in 2008, a change of the legal quality of the declaration cannot be overlooked: From the "mirror coordination instrument" the G-20 has become a "soft decision-making body". Partly the increased influence can be seen in the stronger wordings of G-20 documents; partly specific resolutions and concrete actions are agreed upon by the G-20 Leaders. Therefore, the question arises what legal quality can be attributed to documents released by an international body which is de jure not an international organization with delegated State authority.

\section{Legitimacy in International Law}

\subsection{Notion of Legitimacy}

Legitimacy has to do with authority; generally looking, the concept is to be framed as giving the governed the feeling that their own values are represented in a decision-making context, i.e. as 
establishing an authority's "right to rule". Legitimacy goes linguistically back to the Latin word "legitimus" as meaning "lawful, according to law".

Therefore, legitimacy is based on the notion of enabling "real consensus" between the very many governed; procedures would have to be established which give bargaining power to all of the potential participants in a given matter and thus ensure equal opportunities (R. H. Weber, 2009).

\subsection{Concepts of Legitimacy}

Scholars from different disciplines have looked into different concepts of legitimacy. Taking a sociological perspective, Max Weber, by analyzing the general reasons why State authority is factually accepted, distinguished three ideal types of governance (M. Weber, 1976): The rational or legal, the traditional and the charismatic authority. Legitimacy may further be understood in a wider sense, encompassing an ethical-philosophical dimension, which heaves legitimacy above positive law (Clark, 2005). A similar differentiation has been adopted by scholars distinguishing between "normative theories" on legitimacy, which set out general criteria for evaluating the right to rule, and "empirical theories", which focus on belief systems of those subject to government. In other words, legitimacy can either be justified by formal ideas as the rule of law (legality) or by substantial value rationality based on morality and justice (R. H. Weber, 2009).

The legitimacy of policy-making decisions on global issues may be enhanced by procedural aspects within the different governing entities. This comprehension of legitimacy can be traced back to Niklas Luhmann who founded the doctrine of gaining legitimization by adequate procedures (Luhmann, 1975). Similarly, Thomas M. Franck described legitimacy as "aspect of governance that validates institutional decisions as emanating from a right process. What constitutes right process is described in a society's adjectival constitution or rules of order, or is pedigreed by tradition and historic custom" (Franck, 1995).

The procedural approach is complemented by a result-oriented type of legitimacy, i.e. a substantive conception which looks at the outcome of the legitimizing procedures. This resultoriented approach will depend, not least, on the values deemed as "right" by the stakeholders concerned, thus, in part leading back to questions on legitimizing sources. The problem of the approach consists in the fact that it relies on subjective perceptions of legitimate values which depend on cultural and societal differences and evolve over time (R. H. Weber, 2009).

Therefore, in view of the difficulty to operationalize the result-oriented legitimacy, Jürgen Habermas tried to link the procedural aspects with specific notions of contents derived from the "discourse principle", assuming that just those norms can claim validity which receive the approval of potentially affected people, insofar as they participate in a free rational discourse (Habermas, 1992).

\subsection{Legitimacy and Democracy}

The described conduct directed towards legitimacy must further be measured in the light of the constitutional values and principles. Indeed, Jan Clark specifies "three cognate concepts legality, morality, and constitutionality", which are said to "mark out the terrain within which the practice of legitimacy tends to take place" (Clark, 2005). Legitimacy is thereby perceived as a 
reconciling norm, enabling consensus on how these three elements can be accommodated amongst each other.

In this sense, legitimacy provides for valuable elements of a democratic order. According to a source-oriented perception of legitimacy, for example, an authority may be qualified as legitimate when referring to democratic governing bodies which base their authority on the "demos", the public.

The described perceptions of legitimacy emphasize the concept's origin in the political sciences, i.e. the concept's primary applicability to nation States. Legitimacy on international levels and legally not well structured markets (such as in the field of the Internet or global financial product distribution) as a particular field of international policies is in fact challenged by the role it plays in international law; therefore, with international law gaining importance, legitimacy questions become more significant not only for the international society in general, but also for the stability of the international order (R. H. Weber, 2009).

Consequently, legitimacy must be complemented by democratic elements. (i) According to the source-oriented perception of legitimacy, an authority may be qualified as legitimate if founded in the "demos", the people. (ii) The procedural approach of governance encompasses aspects validating institutional decisions as emanating from a fair and participatory process. (iii) The result-oriented type of legitimacy is a substantive conception looking at the outcome of the legitimizing procedures, trying to get all potentially affected people involved in a rational discourse (R. H. Weber, 2009).

Summarizing the aforementioned thoughts on legitimacy, it cannot be overlooked that a clear-cut understanding of legitimacy does not exist and that its contents depend on the political and social environment; however, notwithstanding these challenges, legitimacy issues should actually be addressed in the field of international financial markets. The governance of these markets encompassing many actors such as nation States, international organizations, non-governmental organizations and private actors must be built on legitimate structures. Since the term legitimacy is so ample, ways of intertwining the different stakeholders concerned, each with distinctive features, becomes imperative. 


\section{Involvement of the G-20 in Regulatory Topics}

\subsection{Overview}

During the first almost ten G-20 summits many action plans, recommendations and resolutions covering a wide range of topics have been adopted, partly in the form of general commitments, partly in the form of specific actions. Summarizing, the following overview shows the addressed legal topics:

Relevant topics of the Washington Summit of November 2008

The first G-20 summit released the basic G-20 Action Plan encompassing a general regulatory framework for international financial markets:

- Transparency and Accountability

$\circ$ Sound Regulation

- Oversight

- Risk Management

- Integrity in Financial Markets

- International Cooperation

- Reforming International Financial Institutions

Relevant topics of the London Summit of April 2009

- Financial Stability Board (FSB)

- Extended scope of regulation and oversight

- Principles on pay and compensation

- Tax transparency

- Credit rating agencies

- Additional resources for the IMF

Relevant topics of the Pittsburg Summit of September 2009

- Framework for strong, sustainable and balanced global growth

- Coordinated exit from state support

- Strengthening the international financial regulatory system

- Modernizing global institutions (IMF and Multilateral Development Banks)

- G-20 as the premier forum for international economic cooperation

Relevant topics of the Toronto Summit of June 2010

- Recovery from the ongoing global recession and the European debt crisis

- Evaluating the progress of financial reform

- Developing sustainable stimulus measures

- Debating global bank tax

- Promoting open markets

- Different solutions' approaches for not identical economies

- EU: Focus on austerity to cut the deficits

○ US: Maintain economic stimulus spending to encourage growth 
Relevant topics of the Seoul Summit of November 2010

- Several mid- and long-term policy issues

○ Ensuring global economic recovery

- Framework for strong, sustainable, and balanced global growth

- Strengthening the international financial regulatory system

- Global financial safety nets

- Risk of a currency war

- Outcome: only limited progress

○ Intention to work on indicative guidelines to set maximum limits for current account surpluses and deficits

- Seoul Development Consensus

Relevant topics of the Cannes Summit of November 2011

- Reform of int. monetary system

$\circ$ more representative

- more stable

- more resilient

- Action plan for growth and jobs

- Further topics

$\circ$ Guiding the management of capital flows

- Cooperation between IMF and regional financial arrangements

- Global governance

○ Poverty mitigation

○ Euro zone crisis

Relevant topics of the Los Cabos (Mexico) Summit of June 2012

- Supporting economic stabilization and the global recovery

- Employment and social protection (e.g. The los Cabos Growth and Jobs Action Plan)

- Strengthening the international financial architecture

- Reforming the financial sector and fostering financial inclusion

- Enhancing food security and addressing commodity price volatility

- Promoting longer-term prosperity through inclusive green growth

- Intensifying the fight against corruption

\subsection{From Microeconomic to Macroeconomic Regulation}

Financial regulation has traditionally been based on microeconomic elements, such as capital adequacy rules, liquidity rules, fit and proper principles or risk management provisions. The financial crisis of 2007/08 has shown that macroeconomic elements must play a more important role, for example the general cooperation on economic policies, the interest rate policies of Central Banks, the fiscal provisions stimulating economic growth (including fiscal sustainability and infrastructure spending), and the proper mitigation of the social consequences of the financial crisis.

In this context, the G-20 has involved itself in the ongoing efforts to improve economic cooperation; examples are the "G-20 Framework for Strong, Sustainable and Balanced Growth" and the charter looking for sustainable economic activity with the heading of "Core Values for 
Sustainable Economic Activity". The Pittsburgh Summit declaration particularly referred to avoiding "fragmentation of markets, protectionism, and regulatory arbitrage".

A specific aspect of macroeconomic regulation leads to the involvement of the Financial Stability Board (FSB) into the periodic peer review processes of the IMF related to the maintenance of financial stability by IMF Member States. Thereby, a new instrument has been created, namely the early warning exercises which are to be conducted jointly by FSB and IMF, the results of which are to be reported to the G-20 Leaders.

\subsection{Reform of International Organizations}

The G-20 has been the main forum addressing the reform of the IMF and the World Bank Group. Specific topics are:

- Increase of the resources available to the IMF and new policies in the lending field (New Arrangements to Borrow, NAB);

- $\quad$ Coordination of the reform on IMF quota and voting rights by supporting the respective amendments to the Articles of Association of the IMF;

- $\quad$ Protection of the voting share of the poorest countries in the IMF, encompassing (i) the size of increases in IMF quotas, (ii) the composition of the Executive Board, (iii) the improvement of the Board's effectiveness and (iv) the strategic oversight of the IMF activities.

An additional element concerns the better coordination of the policies implemented by the Bretton Woods institutions on the one hand and the World Trade Organization (WTO) on the other hand. A key issue is not to introduce new trade barriers for the protection of domestic producers; in the Washington Summit Declaration it is said that the States "will refrain from raising new barriers to investment or to trade in goods and services, imposing new expert restrictions".

\subsection{Regulatory Cooperation}

Cooperation and coordination are important characteristics of regimes of decentered governance as in financial markets and may be considered to be constituting the core of their existence (Senn, 2011). The ongoing fragmentation of legal rules in global markets has constituted the existing system of decentered governance making it necessary to work together in order to ensure the functioning of the system as a whole (coordination of activities, exchange of information, etc.).

Already at the Washington Summit in November 2008, the G-20 has advocated for a better regulatory cooperation between the supervisory authorities of the nation States by adopting "Common Principles of Reform for Financial Markets". They state that: "our financial markets are global in scope, therefore, intensified international cooperation among regulators and strengthening of international standards, where necessary, and their consistent implementation is necessary to protect against adverse cross-border, regional and global development affecting international financial stability". 
From an organizational point of view, the G-20 has established the Financial Stability Board (FSB) as the successor to the Financial Stability Forum (FSF) at the occasion of the London Summit in April 2009. The FSB has an expanded membership and in particular a broadened mandate, including the promotion of financial stability, the elaboration of criteria for compensation schemes, the establishment of a framework for the resolution of financial institutions, etc.

Furthermore, global financial governance also means that the different institutions entrusted with different roles in the financial markets improve their cooperation. Financial supervisory authorities need to strengthen the exchange of information and the collaboration particularly in regarding the supervision of financial conglomerates. A good example for a discussion of the possible instruments of cooperation can be seen in the Consultative Document of the Basel Committee on Banking Supervision, the Joint Forum, outlining "Principles for the supervision of financial conglomerates", dated December 2011.

\section{New Concepts of International Law}

The traditional principles of international law - in particular the notion of sovereignty known since the Westphalian Peace Treaty - are not suitable to cope with the present needs of an international order anymore (R. H. Weber, 2010b). Nation states loose possibilities to exclusively regulate legal issues on a territorial basis since cross-border effects of businesses lead to the need to have increased co-operation. Furthermore, the often cited phrase that "almost all nations observe almost all principles of international law and almost all of their obligations almost all of the time" (Henkin, 1979) seems to be a hardly convincing assertion anymore. Moreover, the increasingly dense framework of rules with different legal qualities rather leads to uncertainties in respect of the compliance with rules by their addressees. Therefore, the development of new legislative concepts becomes imperative.

\subsection{Informal Law-making}

Since a few decades, legal doctrine has been looking at possibilities and at the concretization of different forms of "informal" law-making. Soft law is often used as an overarching term (Brummer, 2012), however, other terminologies are also available. "Informal" law-making means that rules are elaborated and implemented by bodies not having sovereign power in the traditional sense. Examples can be found in many areas, particularly in fields coined by fast technological developments (R. H. Weber, 2010a).

Informal law-making is on the rise, thereby challenging traditional mechanisms of democratic accountability. The informal international law-making can be seen as encompassing three main features, namely: (i) Process-informality leading to norms developed not in treaty-based forms, but in networks, fora or G-groups often without international legal personality; (ii) actorinformality encompassing private actors, industry associations, civil society and other organizations or networks; (iii) output-informality leading to norms that are not formal hard law sources, but standards, non-binding guidelines or indicators most of which are outside of the 
remit of the traditional legal order (Pauwelyn, 2011). The challenge of informal law-making consists in maintaining the law's neutrality and protective force and in balancing informality which may be needed to enable effective cooperation to avoid traditional strictures (R. H. Weber, 2012); such an approach will require a shift in international law from being a value-free instrument enabling state-to-state cooperation to a genuine regulatory order as well as a process balancing effectiveness with democratic accountability (Pauwelyn, 2011).

The dichotomy between the law and practical habitudes caused by the information technologies' developments including the socio-economic problems can also be analyzed under the perspective of a framework of "Internet-ional" legal principles based on the history of customs as source of law (Chik, 2010). This approach underlines the suitability of customary international rules as a template for formulating Internet law-making rules by adapting customary rules to develop a set of determinants for Internet law (Chik, 2010).

\subsection{Incorporation of Norms through Informal Processes}

Informal law-making as such does not suffice; the declarations, statements, undertakings etc. need to be implemented into some kind of legal framework. The most traditional way would consist of having the informal norms being taken up by an established formal body; for example, certain aspects of the G-20 propositions have led to an amendment of the Articles of Association of the IMF.

Usually, however, informal law-making is implemented through informal, not directly lawrelated means, for example reputation, reciprocity, or retaliation (Guzman/Meyer, 2010). The most important element is reputation relying on "naming and shaming"; nevertheless, the risk should not be overlooked that wrong or asymmetric information could lead to a false reputation statement. Another problem consists in the potential double function of an entity providing the information and being judged according to this information; the problem can be seen in the information gained by the IMF surveillance efforts which may only be published with the permission of the inspected country.

A further problem concerns the appropriate dissemination of norms being based on informal lawmaking; depending upon the domestic political situation, sensible trade-offs out of the realm of politics without the necessary political deliberation cannot be excluded.

\subsection{Elements of Legitimacy in Informal Situations}

Legally, the G-20 is not based on a stable foundation reflecting the rule of law and the "demos"; moreover, coming from a political angle it was discretionally composed of some countries with the objective to tackle some important financial and economic issues. Its increasing role, however, is associated with some "sovereignty costs" of formal international law (Abbott/Snidal, 2000). Particularly in view of the fact that the traditional sovereignty concept needs to be adjusted to the requirements of a modern world, the consequences of such "sovereignty costs" should be clearly assessed, not at least due to problem that the political foundation of authority could be undermined by decision-making bodies without democratic legitimacy. 
The problem of Declarations and Action Plans released by the G-20 Leaders having a morally "binding" effect does not only consist of the fact that 20 States implement rules that are relevant for 200 States, but also in the fact that the actors do not necessarily have a formal delegation of authority. The G-20 transnational network, partly legitimized with reference to the recently developed approach of "trans-governmentalism" (Slaughter/Zaring, 2005; Slaughter, 2004; Raustiala, 2002; Zaring, 1998), may enable to exercise a "norm entrepreneur" function as experience has shown. At least, the network can boost and enable formal treaty making and influence the development of both hard law and soft law (Posner, 2000). However, further efforts need to be applied in strengthening the authorities' right to rule and in helping countries that do not participate yet in taking advantage of the network's activities.

Legitimacy is a relational concept which is institutionally and discursively constituted (Senn, 2011). Regulatory regimes evolve in view of the societal and political context; insofar, private autonomous regimes can also be legitimate if developed with the objective to increase the institutionalization, thererby based on broad initiation, wide building support, and political legitimacy (Bernstein/Cashore, 2007). Other elements are the significance of the institutional environment, the dynamics of legitimacy relationships, and how non-sovereign bodies respond to multiple legitimacy claims in complex and dynamic regulatory situations (Black, 2008). In relation to non-state or private networks and organizations, emphasis should not be put on normative validity based on value legitimacy; moreover, the trend towards efficiency and interest maximization as a source of legitimacy (Senn, 2011) should be supported, since efficiency and legitimacy are deeply intertwined.

Further important criteria are accountability or control and enforcement: Insofar, the acceptance of informal law-making by the market participants and by civil society is of major importance; gaining the support of the "governed" is a key task, since failing to do so will undermine the legitimacy of the norms enacted (Slaughter, 2004; Senn, 2011). An institutionalized interface between the informal law-making bodies and the addressees in markets and civil society may help to adopt better adapted and accepted norms which increases the degree of accountability and facilitates enforcements.

\subsection{Assessment of the G-20 Legitimacy}

As has been shown, the factual power of the G-20 does not have a stable legal foundation based on traditional legitimacy concepts. Looking from the angle of factual acceptance, the G-20 type of governance cannot be justified with legal authority, perhaps rather with power-oriented arguments. Furthermore, the normative theory of legitimacy cannot serve as or does not provide a reasoning for assuming the G-20 legitimacy; possibly, the empirical theory focusing on belief systems of those subject to governmental authority would be suitable to be taken into account.

A result-oriented model for legitimacy considerations does not adequately fit the G-20 system. Moreover, a procedural approach seems to be more appropriate, assuming that those Action Plans and Declarations of the G-20 can claim legitimacy which receives the approval of potentially affected people, if they participate in a free rational discourse. This procedural approach should 
be further developed within the G-20 framework in order to improve democratic requirements and adequate governance principles.

The recent attempts to develop new concepts of informal law can point into the appropriate direction and help to overcome weaknesses of existing models or approaches. Informal lawmaking is apt to broaden the consensus-building amongst the concerned persons, organizations and other bodies. Different models of informal law-making are available which encompass several aspects validating institutional decisions as emanating from a right process. Consequently, the G-20 Leaders should rely more on such kind of informal processes including elements of reputation and retaliation.

The more the "governed" do have the trust in a participative consensus-building process, the more they will accept the released rules. Such a participative consensus-building could be enhanced if the G-20 Leaders would better liaise with the competent bodies of international organizations encompassing a higher number of members, in particular the International

Monetary Fund (IMF)/World Bank Group, the World Trade Organization (WTO), the International Labor Organization (ILO) and other UN bodies; these organizations cover the major fields of international business, namely finance, trade and labor; furthermore, cooperation arrangement already exist between these entities. If IMF/World Bank and WTO are involved in the decision-making processes of the G-20 Leaders, countries and civil society not represented in the "exclusive" small group could more easily accept to comply with declarations and statements released by the G-20.

\section{Bibliography}

Abbott, Kenneth W./Snidal, Duncan, Hard and Soft Law in International Governance, International Organization, Vol. 54, 2000, 429.

Bernstein, Steven/Cashore Benjamin, Can non-state global governance be legitimate? An analytical framework, Regulation \& Governance, Vol. 1, 2007, 347.

BLACK, JULIA, Constructing and contesting legitimacy and accountability in polycentric regulatory regimes, Regulation / Governance, Vol. 2, 2008, 137.

Brummer, Chris, Soft Law and the Global Financial System. Rule Making in the $21^{\text {st }}$ Century, Cambridge 2012.

ChIK, WARren B., "Customary Internet-ional Law": Creating a Body for Customary Law for Cyberspace, Computer Law \& Security Review, Vol. 26, 2010, 3.

CLARK, IAN, Legitimacy in International Society, New York 2005.

FRANCK, ThOMAS M., Fairness in International Law and Institutions, Oxford 1995.

Guzman, Andrew T./Meyer, Timothy L., International Soft Law, Journal of Legal Analysis, Vol. 2, 2010, 171. 
HAbermas, Jürgen, Faktizität und Geltung, Beiträge zur Diskurstheorie des Rechts und des domokratischen Rechtsstaats, Frankfurt 1992.

HenKIN, LouIs, How Nations Behave, $2^{\text {nd }}$ ed., New York 1979.

LUHMANN, NiKLAS, Legitimation durch Verfahren, $2^{\text {nd }}$ ed., Darmstadt/Neuwied 1975.

PAuwelyn, JoOst, The Rise and Challenges of "Informal" International Law-Making: Muller/Zouridis/Frishman/Kristemaker (eds.), The Law of the Future and the Future of Law, Oslo 2011, 125.

POSNER, ERIC, Law and Social Norms, Cambridge Mass. 2000.

Raustiala, KAL R., The Architecture of International Cooperation: Transgovernmental Networks and the Future of International Law, Virginia Journal of International Law, Vol. 43, 2002, 1 .

Senn, Myriam, Non-State Regulatory Regimes. Understanding Institutional Transformation, Heidelberg/Berlin 2011.

Slaughter, AnNe-Marie, A New World Order, Princeton/Oxford 2004.

Slaughter, Anne-Marie/Zaring, David, Networking Goes International, An Update, Annual Review of Law and Social Science, 2006, 215.

WEBER, MAX, Wirtschaft und Gesellschaft, Grundriss der verstehenden Soziologie, $5^{\text {th }}$ ed., Tübingen 1976.

Weber, Rolf H., Shaping Internet Governance: Regulatory Challenges, Zurich 2009.

Weber, Rolf H. (2010a), New Rule-Making Elements for Financial Architectures Reform, Journal of International Banking Law and Regulation, Vol. 25, 2010, 512.

Weber, Rolf H. (2010b), New Sovereignty Concepts in the Age of Internet?, Journal of Internet Law, August 2010, 12.

Weber, Rolf H., The Future of (Cyber-) Law, forthcoming.

ZARING, DAVID, International Law by Other Means: The Twilight Existence of International Financial Regulatory Organizations, Texas International Law Journal, Vol. 33, 1998, 281. 